\title{
Tools for the development of a benthic quality index for Italian lakes
}

\author{
Bruno ROSSARO*, Angela BOGGERO ${ }^{1)}$, Valeria LENCIONI'), Laura MARZIALI') and Angelo SOLIMINI ${ }^{3)}$ \\ Department of Biology, Section of Ecology, University of Milano, Via Celoria 26, 20133 Milano, Italy \\ ${ }^{1)}$ CNR Institute of Ecosystem Study, Largo V. Tonolli 50, 28922 Verbania Pallanza (VB), Italy \\ ${ }^{2)}$ Section of Invertebrate Zoology and Hydrobiology, Natural Science Museum, Via Calepina 14, 38100 Trento, Italy \\ ${ }^{3)}$ European Commission, Joint Research Centre, Via Fermi 1, 21020 Ispra (VA), Italy \\ * e-mail corresponding author: bruno.rossaro@unimi.it
}

\begin{abstract}
In this paper, we propose a methodology to develop a benthic quality index useful for Italian lakes. The existing data about benthic macroinvertebrates of the Italian lakes were collected over a period of 50 years, but only a few lakes such as the Maggiore and the Mergozzo have been intensely studied. Some large lakes such as Lake Como are still almost uninvestigated. In total, 570 benthic macroinvertebrate taxa were identified; of which 373 belong to Chironomidae and 85 to Oligochaeta. With the aim of relating environmental variables with macrobenthos assemblages, we carried out a canonical correlation analysis (CANON) using a database that included 1060 sampling points. Both environmental (13 variables describing morphometry and hydrochemistry) and biological data (57 taxa) were available, but only taxa present in at least 10 samples were selected for data analysis. Three canonical variates were ecologically significant. The first one was correlated with conductivity, $\mathrm{pH}$ and alkalinity and accounted for $20 \%$ of the total variation. The second one was positively correlated with total phosphorus and $\mathrm{N}-\mathrm{NH}_{4}$, and inversely with dissolved oxygen, and accounted for $18 \%$ of the total variation. The third one showed a direct correlation with maximum lake depth and volume and an inverse correlation with water temperature, and accounted for $17 \%$ of the total variation. A Trophic Status Index (TSI), based on the table 11 of the Italian Law 152/99 (without including chlorophyll), was calculated by ranking percent oxygen saturation, transparency and total phosphorus. TSI was used to test a Benthic Quality Index for Italian Lakes (BQIL) which is proposed in the present paper. The algorithm considered three steps. First, the means of three variables were calculated: percent oxygen saturation, transparency and total phosphorus weighted by the taxa abundances. These values are interpreted as optimum for each taxon and used to assign an indicator weight (BQIW). Second, the mean of these three variables was calculated for each taxon (mean BQIW). Third, the mean BQIW was multiplied by taxa abundance and divided by the total number of specimens present at each site for which the BQIL was obtained. Using a regression between BQIL and TSI values, lake sites were assigned to 5 quality classes as required by the Italian Law 152/99 and the WFD 2000/60/CE. This assignment must be considered as tentative, because different lake types should be considered separately to develop an index. At present the lack of information from different lake typologies hinders the development of a more sophisticated index such as the French Lake Biotic Index (LBI).
\end{abstract}

Key words: bioindicators, lakes, chironomids, oligochaetes, multivariate analysis, trophic status

\section{INTRODUCTION}

\subsection{State of knowledge on the study sites}

Northern sub-alpine and Central volcanic lakes constitute two of the largest Italian lake districts and include more than $90 \%$ of the entire Italian freshwater volume. They have high ecological and environmental value and are valuable resources of water within densely populated areas. These characteristics explain the high interest that researchers have had in lowland lakes. The management and conservation of the quality characteristics and the maintenance of biodiversity currently represents a topic of major importance because of the need for technical support and scientific data for planning necessary interventions.

The papers included in the present database (Tab. 1) only represent a part of the studies carried out on the macrofauna of Italian lakes; thus, this is not a complete review of the knowledge about this theme. For example, the volcanic lakes sampled in Central Italy (Seminara et al. 1990; Bazzanti et al. 1998) were not considered, because the detailed data were not available. The samples selected for the present analysis included quantitative benthic macroinvertebrate counts, water chemical analyses and environmental variables.

The macrobenthos of some Italian lakes was investigated in the past, but there are many gaps in knowledge. Many contributions are in Memorie dell'Istituto Italiano di Idrobiologia (now Journal of Limnology) concerning the macrozoobenthos of Italian lakes since the '50s. Macrozoobenthos was analyzed in littoral, sublittoral and profundal zones with different sampling strategies and time schedules (Tab. 1).

It must be emphasized that, in general, the investigations were limited to large taxonomic groups without detailed taxonomic information, or they were restricted to a single group (e.g. chironomids, Mietto et al. 2000). Moreover, the data available are from a very small proportion of lakes such as the ones reported in "Catasto dei laghi Italiani" (Gaggino \& Cappelletti 1984) and most investigations refer to ' 60 s and '70s. 
Tab. 1. List of lakes and papers considered to develop the database and concerning: $\mathrm{L}=$ littoral, $\mathrm{SL}=$ sublittoral, $\mathrm{P}=$ profundal.

\begin{tabular}{|c|c|c|c|c|}
\hline Lakes & $\mathrm{L} / \mathrm{SL}$ & $\mathrm{P}$ & Sampling method & N. taxa \\
\hline Alserio & Ceretti \& Nocentini 1996 & Bonomi et al. 1967 & Ekman grab, net sludge & 44 \\
\hline Annone Est & Ceretti \& Nocentini 1996 & Bonomi et al. 1967 & Ekman grab, net sludge & 27 \\
\hline Annone Ovest & & Bonomi et al. 1967 & Ekman grab, net sludge & 10 \\
\hline Bolsena & Nocentini 1973, 1974 & Bonomi \& Ruggiu 1968 & Petersen grab & 74 \\
\hline Bracciano & Nocentini 1973, 1974 & & Petersen grab & 60 \\
\hline Comabbio & Ceretti \& Nocentini 1996 & & net sludge & 42 \\
\hline Endine & Nocentini et al. 1974 & & Petersen grab & 29 \\
\hline Garda & & Bonomi 1974 & Petersen grab & 279 \\
\hline Garlate & Ceretti \& Nocentini 1996 & & net sludge & 48 \\
\hline Ghirla & Ceretti \& Nocentini 1996 & & net sludge & 59 \\
\hline Iseo & & Bonomi \& Gerletti 1967 & Petersen grab & 25 \\
\hline Maggiore & $\begin{array}{l}\text { Lenz 1954; Nocentini 1963, } \\
1988,1991\end{array}$ & $\begin{array}{c}\text { Corbella et al. } 1956 ; \text { Bonomi } \\
\text { et al. } 1979\end{array}$ & Ekman\&Petersen grab, net sludge & 131 \\
\hline Mergozzo & Nocentini 1966, 1979 & Ruggiu \& Saraceni 1972 & Petersen grab & 104 \\
\hline Monate & Ceretti \& Nocentini 1996 & & net sludge & 36 \\
\hline Montorfano & Ceretti \& Nocentini 1996 & Bonomi et al. 1967 & Ekman grab, net sludge & 30 \\
\hline Pertusillo & & Bonomi \& Andreani 1978 & Petersen grab & 15 \\
\hline Pusiano & Ceretti \& Nocentini 1996 & Bonomi et al. 1967 & Ekman grab, net sludge & 55 \\
\hline Sartirana & Ceretti \& Nocentini 1996 & & net sludge & 24 \\
\hline Segrino & Ceretti \& Nocentini 1996 & Bonomi et al. 1967 & Ekman grab, net sludge & 24 \\
\hline Varese & Ceretti \& Nocentini 1996 & Bonomi 1962, 1964 & grab, net sludge & 72 \\
\hline Vico & Nocentini 1973, 1974 & & Petersen grab & 49 \\
\hline
\end{tabular}

The database available is not suitable to build a model to forecast lake evolution over long scales. New samplings are necessary to test a benthic quality index. The development of a biotic index must be considered tentative with the present state of knowledge.

\subsection{The benthic quality indices}

Several indices and classification systems were developed using benthic macroinvertebrates. Oligochaetes and chironomids were considered the most useful indicators of oxygen conditions (Brundin 1949) and trophic status (Sæther 1979).

Lake classification using benthic macroinvertebrates has been developed for Central European and Scandinavian lakes (Wiederholm 1981; Aagaard 1986; Kansanen et al. 1990; Johnson et al. 1993). Chirononomids and oligochaetes showed a different distribution according to depth, oxygen saturation and trophic conditions (Lenz 1925; Naumann 1932; Lundbeck 1936; Thienemann 1954; Brundin 1956, 1974).

The trophic indices developed for lakes of Northern Europe relied on the relative abundances of chironomid taxa, the ratio of tolerant to intolerant tubificid oligochaetes, and the ratio of oligochaetes to chironomids (Wiederholm 1980). Wiederholm (op. cit.) also developed a Benthic Quality Index (BQI) based on chironomids, giving 6 different score levels as indicator values:

$$
B Q I_{i}=\sum_{j=0}^{5} \frac{h_{j} y_{i j}}{\sum_{j=0}^{5} y_{i j}}
$$

where $y_{i j}=$ number of individuals of each indicator group $j$ in site $i, \sum_{j=0}^{5} y_{i j}=$ total number of individuals of all indicator groups $j$ in site $i, h_{j}$ is the score level which ranges from 0 to 5 according to the indicator value given to different taxa.

Sæther $(1979,1980)$ developed a classification system identifying 15 lake groups using profundal, sublittoral and littoral chironomid assemblages from Nearctic and Palaearctic lakes. Community structure varied in relation to the increasing ratio between phosphorus concentration and depth. The chironomid assemblages proposed include many taxa never recorded in Italy, so the system cannot be applied to Italian lakes without a substantial revision. Wiederholm (1980) and Lang (1985) developed benthic quality indices for oligochaetes as well. Verneaux et al. (2004) and Borderelle et al. (2005) discussed a Lake Biotic Index (LBI) based on the comparison of littoral and profundal macroinvertebrate communities sampled in soft sediments. A recent review of benthic macroinvertebrate indices is in Le Foche et al. (2005).

The Water Framework Directive 2000/60/CE (WFD) requires an assessment of either high, good, moderate, poor or bad ecological status using different components of biotic community. The aim of the present paper is to propose a Benthic Quality Index which uses the same conceptual framework proposed by Wiederholm (1980), summarized in equation $(1$, and that uses all the most common taxa among macroinvertebrates living in the Italian lakes (acronym: BQIL). 


\section{MATERIALS AND METHODS}

\subsection{Sampling methods}

For the papers considered in this data analysis benthic macroinvertebrates were collected from soft bottom samples with an Ekman or a Petersen grab (Corbella et al. 1956; Nocentini 1979, 1989) or with a net sludge (Tab. 1). Samples were collected in late winter - early spring during the period of full circulation and in summer during stratification. Samples were sieved on a 250 $\mu \mathrm{m}$ mesh and fixed in $10 \%$ neutralized formaldehyde. The number of specimens for each taxon was counted using a stereomicroscope. For details see the original papers.

\subsection{The taxa and stations analyzed}

In the lakes examined 570 macroinvertebrate taxa were captured, 373 of which belonged to chironomids. Among the chironomid taxa, 43 belonged to the subfamily of Tanypodinae, 18 to Diamesinae, 3 to Prodiamesinae, 151 to Orthocladiinae (including 31 terrestrial taxa), 158 to Chironominae (63 to Tanytarsini, 94 to Chironomini and 1 to Pseudochironomini). The most represented group after Chironomidae was Oligochaeta with 85 taxa, and the other aquatic insects with 67 taxa. Mollusca were present with 37 taxa, Crustacea with 8 taxa.

At present a database is available with almost 20,000 records of macroinvertebrates collected in small and large Italian lakes. Samples were selected considering the availability of both environmental variables and quantitative benthic samples: 1060 samples were used including 13 environmental variables (Tab. 2) and 57 taxa, mostly oligochaetes and chironomids; the taxa present in at least 10 samples were selected for data analysis.

Tab. 2. Environmental variables used in data analysis.

\begin{tabular}{lcc}
\hline Description & Abbreviation & Unit of measure \\
\hline Latitude (large set) & lat & Gauss Boaga \\
Longitude (large set) & long & Gauss Boaga \\
Lake volume & vol & $\mathrm{m} 3$ \\
Maximum depth of lake & max depth & $\mathrm{m}$ \\
Depth of sampling site & depth & $\mathrm{m}$ \\
Water temperature & temp & ${ }^{\circ} \mathrm{C}$ \\
Transparency & transp & $\mathrm{m}^{-1}$ \\
Conductivity & cond & $\mu \mathrm{S} \mathrm{cm}^{-1}$ \\
Alkalinity & alkal & $\mathrm{mg} \mathrm{l}^{-1}$ \\
pH & $\mathrm{pH}$ & \\
Oxygen content & $\mathrm{O} 2$ & $\mathrm{mg} \mathrm{l}^{-1}$ \\
Percent $\mathrm{O}_{2}$ saturation & $\mathrm{O}_{2} \%$ sat & $\%$ \\
Total phosphorus & $\mathrm{TP}$ & $\mu \mathrm{g} \mathrm{l}^{-1}$ \\
Nitrate & $\mathrm{N}-\mathrm{NO}_{3}$ & $\mu \mathrm{g} \mathrm{l}^{-1}$ \\
Ammonia & $\mathrm{N}-\mathrm{NH}_{4}$ & $\mu \mathrm{g} \mathrm{l}^{-1}$ \\
\hline
\end{tabular}

The database included 21 lakes that included small and large lakes in Northern Italy, volcanic lakes in Central Italy and one artificial lake in Southern Italy
(Basilicata Region). The lakes considered were divided into 6 groups:

1 small lakes with volumes lower than $70 \times 10^{6} \mathrm{~m}^{3}$ : Monate, Comabbio, Montorfano, Alserio, Pusiano, Annone Est, Annone Ovest, Segrino and Endine;

2 L. Mergozzo with a volume of $73 \times 10^{6} \mathrm{~m}^{3}$ constitutes the second group; it was well analysed in the '70s and is characterised by a very low conductivity;

3 L. Pertusillo, an artificial lake from Basilicata Region (Southern Italy);

$4 \mathrm{~L}$. Varese, for which an historical data series is available since the '50s;

5 L. Vico, L. Bracciano and L. Bolsena (volcanic lakes in Central Italy);

6 large lakes (L. Maggiore, L. Iseo and L. Garda) with a volume larger than $5000 \times 10^{6} \mathrm{~m}^{3}$.

\section{DATA ANALYSIS}

Physical (lake volume, depth, water temperature, etc.), chemical ( $\mathrm{pH}$, conductivity, oxygen, TP, $\mathrm{N}-\mathrm{NO}_{3}$, $\mathrm{N}-\mathrm{NH}_{4}$, etc.) (Tab. 2), and biological variables (macroinvertebrate taxa, including oligochaetes, crustaceans, aquatic insects, and molluscs) were analyzed. Chemical measures referred to either hypolimnic values during stratification or to the mean water column values during full circulation. Environmental data expressed using different units of measurement were standardized by subtracting the mean and dividing by the standard deviation. Taxa abundances per square meter were log transformed before data analysis. Microsoft ACCESS (MSA) ${ }^{\circledR}$ was used to store information (Rossaro et al. 2001). Data were exported from MSA into Matlab 7.2 ${ }^{\circledR}$ for all the other data analysis. Calculations of Trophic Status Index (TSI), Benthic Quality Index Weight (BQIW) and Benthic Quality Index Lakes (BQIL) were performed using a Matlab program written by the senior author.

\subsection{Trophic Status Index and Benthic Quality Index}

Total phosphorus (TP), Secchi transparency, chlorophyll- $a$ content and different forms of organic and inorganic nitrogen were used to describe and summarize the trophic status of lakes (Carlson 1977). The application of these concepts to the eutrophication of the Italian lakes was considered by Chiaudani et al. (1983). At present the Italian Law 152/99 (table 11) defines five quality classes (where class 1 is the best and class 5 is the worst) using TP, transparency, percent of hypolimnetic oxygen saturation and chlorophyll- $a$ to describe the trophic status of lakes. In comparison with Carlson's TSI, percent of hypolimnetic oxygen saturation was also included. These variables were rescaled in an interval from 1 to 100, the lowest values of TP, chlorophyll-a and the highest values of transparency, and percent oxygen saturation were set to 100 . The highest values of TP, chlorophyll- $a$ and the lowest values of transparency, and percent oxygen saturation were set to 1 . The lakes 
can be ranked and the mean of the variables for each lake can be calculated to summarize the ecological status using a TSI value. In Gaggino et al. (1985), chlorophyll- $a$ was not included in the analysis because of the reduced number of observations. As in Gaggino et al. (op. cit.), we also considered three variables to calculate the TSI: TP, transparency and percent of oxygen saturation.

The weighted means and standard deviations of the three variables for each taxon were calculated, using the species abundances as the weighting factor, according to the following formula:

$$
\bar{z}_{j k}=\frac{\sum_{i=1}^{n} y_{i j} z_{i k}}{\sum_{i=1}^{n} y_{i j}} \quad \bar{s}_{j k}=\sqrt{\frac{\sum_{i=1}^{n} y_{i j}\left(z_{i k}-\bar{z}_{j k}\right)^{2}}{\frac{(n-1)}{n} \sum_{i=1}^{n} y_{i j}}}
$$

where $z_{i k}$ is the value of the environmental variable $k$ measured in a locality $i, y_{i j}$ is the abundance of the taxon $j$ in the same locality $i, \bar{z}_{j k}$ is the weighted mean and $\bar{S}_{j k}$ is the standard deviation calculated for the taxon $j$ and the environmental variable $k$. Weighted means and standard deviations can be interpreted as optimum and tolerance values for each taxon (Ter Braak \& Prentice 1988). To develop the benthic quality index (BQIL), the means were used as a weight (BQIW: Benthic Quality Index Weight) and assigned to each taxon. The weighted means were rescaled to between 5 and 1 according to the following formula (Lek \& Guégan 2000): (this facilitates the assignment of lakes to 5 quality classes as requested by the Italian Law 152/99 and the WFD 2000/60/CE):

$$
\breve{z}_{j k}=\frac{\left(\bar{z}_{j k}-z_{\text {min }}\right)}{\left(z_{\text {max }}-z_{\text {min }}\right)} *(5-1)+1
$$

where $\bar{z}_{j k}$ is the weighted mean of each taxon $j$ and environmental variable $k$ as above and $\check{z}_{j k}$ is the rescaled weighted mean. In the present case $k$ refers to one of the $q=3$ environmental variables selected to build TSI. TP is assumed to decrease with water quality, whereas transparency and percent of oxygen saturation are assumed to increase, so $\check{z}_{j T P}$ was rescaled:

$$
\breve{z}_{j T P}=5-\breve{z}_{j T P}+1
$$

The indicator weight $B Q I W_{j}$ was obtained by taking the means of the rescaled $\check{z}_{j k}$ according to the formula:

$$
\mathrm{BQIW}_{j}=\sum_{k=1}^{q} \frac{\breve{z}_{j k}}{q}
$$

where: $q=$ number of environmental variables used to calculate $B Q I W$ ( 3 in the present case); $\check{z}_{j k}=$ rescaled mean value of the environmental variable $k$ weighted by the abundance of the taxon $j$. At this point, $B Q I W_{j}$ assumes values comprised between 1 and 5 .

As a last step, $B Q I L_{i}$ for each site $i$ was calculated using the modified Wiederholm's (1980) formula (see Equation 1), using the $B Q I W j$ weights instead of the $h$ values in the equation (1:

$$
B Q I L_{i}=\frac{\sum_{j}^{p} B Q I W_{j} y_{i j}}{\sum_{j}^{p} y_{i j .}}
$$

where: $p=$ the number of taxa in the site $i ; B Q I W_{j}=$ the indicator weight of the taxon $j ; y_{i j}=$ the abundance of the taxon $j$ in the site $i$; $B Q I L_{i}=$ the biotic index of site $i$.

Equation ( 6 can be used to calculate the $B Q I L_{i}$ of a new site starting from the $B Q I W_{j}$ and the abundances $y_{i j}$ of the taxon in the new site.

\subsection{Canonical correlation analysis (CANON)}

A CANON was carried out to analyse the relationships between benthic macroinvertebrates and environmental variables and to summarize the results (Gittins 1979).

The canonical analysis investigates the relationships between variables of two distinct but associated sets; it searches for linear combinations for a set (taxa) of dependent variables which have the maximum correlation with a linear combination of a set of independent variables (environmental variables):

$$
{ }_{n} \mathbf{Y}_{\mathbf{p}} \mathbf{A}_{\mathbf{k}}={ }_{\mathbf{n}} \mathbf{Z}_{\mathbf{q}} \mathbf{B}_{\mathbf{k}}
$$

where $\mathrm{Y}$ are the dependent variables (taxa), $\mathrm{Z}$ are the independent variables (environmental variables), $A$ and $\mathrm{B}$ are the factor loadings estimated to maximize the correlation. The products YA and ZB are the factor scores for the biological and environmental sets respectively. The model is developed for $\mathrm{n}$ sites, $\mathrm{p}$ taxa and $\mathrm{q}$ environmental variables; $\mathrm{k}$ linear combinations are calculated (= canonical variates) that are independent of one another.

\section{RESULTS}

\subsection{Canonical correlation analysis}

The three canonical axes had an eigenvalue greater than 0.5 (Tab. 3). The first axis was associated with a gradient related to ionic concentration, the second with a trophic - hypolimnetic oxygen gradient (Fig. 1), and the third with a morphometric (lake volume and depth) gradient that separated large and deep lakes from small and shallow ones that had higher water temperature and ammonia content. A fourth axis separated large, profundal, transparent lakes from small eutrophic lakes. The factor loadings of the environmental variables are in table 4 . 


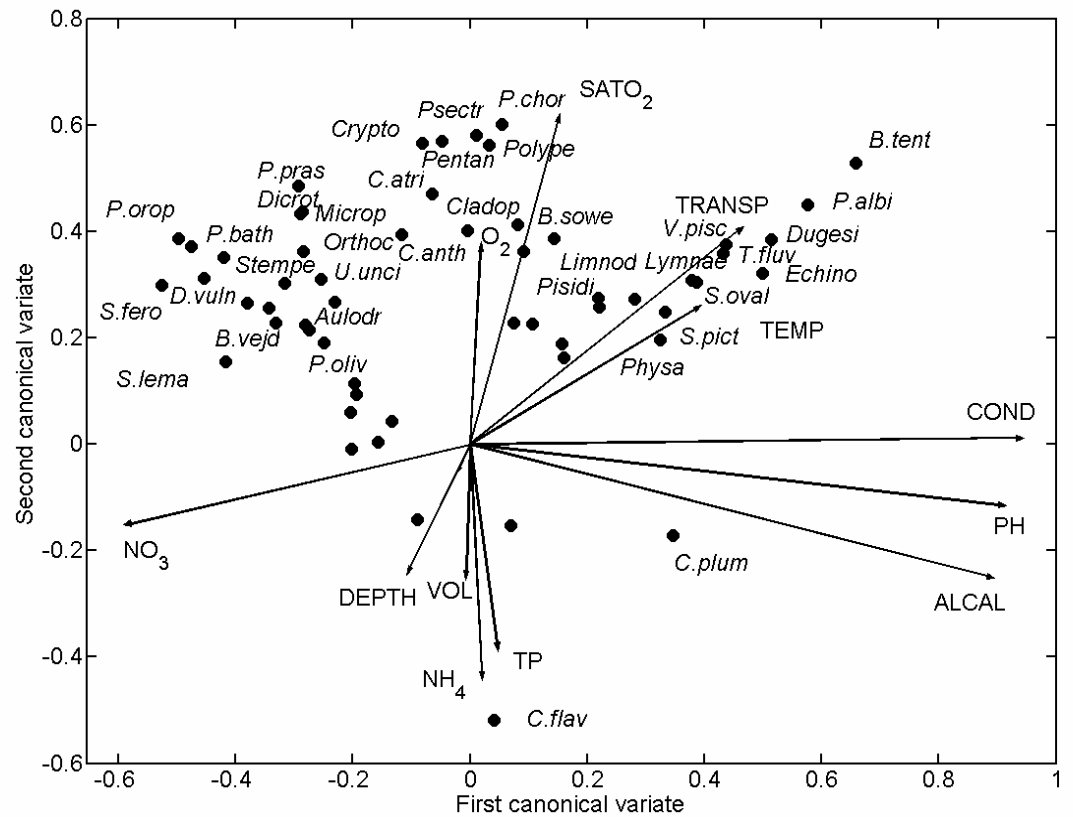

Fig. 1. Biplot of the factor loadings of environmental variables (arrows) and taxa (circles) of the canonical correlation analysis, in the plane defined by the two first axes. Taxa names with absolute values $<0.3$ in both axes were not evidenced.

Tab. 3. Canonical analysis: eigenvalues.

\begin{tabular}{ccc}
\hline canonical axis & eigenvalue & \% total \\
\hline 1 & 0.853 & 20.068 \\
2 & 0.750 & 17.655 \\
3 & 0.708 & 16.673 \\
4 & 0.466 & 10.960 \\
5 & 0.354 & 8.335 \\
6 & 0.248 & 5.847 \\
7 & 0.228 & 5.369 \\
8 & 0.173 & 4.080 \\
9 & 0.154 & 3.616 \\
10 & 0.136 & 3.212 \\
11 & 0.090 & 2.113 \\
12 & 0.057 & 1.341 \\
13 & 0.031 & 0.731 \\
\hline
\end{tabular}

The first canonical axis separated (Fig. 2 and Tab. 4) volcanic lakes in Central Italy with a high conductivity, $\mathrm{pH}$ and alkalinity from subalpine lakes such as L. Mergozzo with a very low conductivity. The trophic condition (Fig. 2 and Tab. 4) was associated with the second axis: the oligotrophic L. Mergozzo and volcanic lakes had low TP content, while the other lakes (as L. Varese) had high TP content.

The factor loadings of taxa are in tables 5 and 6 , and in figure 1. Taxa with high negative values on the first canonical axis (Spirosperma ferox, Pagastiella orophila, Parakiefferiella bathophila, Stylodrilus lemani, Demicryptochironomus vulneratus, Stempellina bausei, Bothrioneurum vejdovskianum, Aulodrilus sp., Prodiamesa olivacea, Uncinais uncinata, Dicrotendipes spp.) were characteristic of waters with low alkalinity, $\mathrm{pH}$ and conductivity, whereas taxa with high positive values on the first canonical axis (Bithynia tentaculata, Paratendipes albimanus, Dugesia sp., Echinogammarus sp., Theodoxus fluviatilis, Valvata piscinalis, Sphaerium ovale, Chironomus plumosus, Lymnaea spp., Physa spp.) were positively correlated with $\mathrm{pH}$, conductivity and alkalinity. High alkalinity was related to high hardness which favoured the Mollusca. Taxa characteristic of eutrophic lakes are plotted in the low part of the plane (Fig. 1).

Few taxa had low factor loadings in the second axis and are positively correlated with $\mathrm{N}-\mathrm{NH}_{4}$ and TP: Chaoborus flavicans, Chironomus plumosus, Tubifex tubifex, Ceratopogonidae and Lumbriculidae. In contrast, many taxa had high factor loadings in the second axis and were positively correlated with oxygen and transparency: Procladius choreus, Polypedilum spp., Pentaneurini spp., Bithynia tentaculata, Psectrocladius spp., Cryptochironomus spp., Paratendipes albimanus, Pseudochironomus prasinatus, Micropsectra spp., Cladotanytarus atridorsum, Chironomus anthracinus (Tab. 6, Fig. 1). Profundal taxa had high loading in the third axis: Asellus aquaticus, Niphargus foreli, Stylodrilus lemani, Spirosperma ferox.

\subsection{TSI, and BQIL results}

The values of the taxa weights (BQIW) are in table 7. The taxa known to be very tolerant ( $C$. flavicans, $C$. plumosus) received very low weight, whereas the less tolerant taxa received high weights: $S$. pictulus, $P$. albimanus among chironomids, S. ovale, T. fluviatilis, $B$. tentaculata among molluscs and Echinogammarus sp. among Crustacea. 


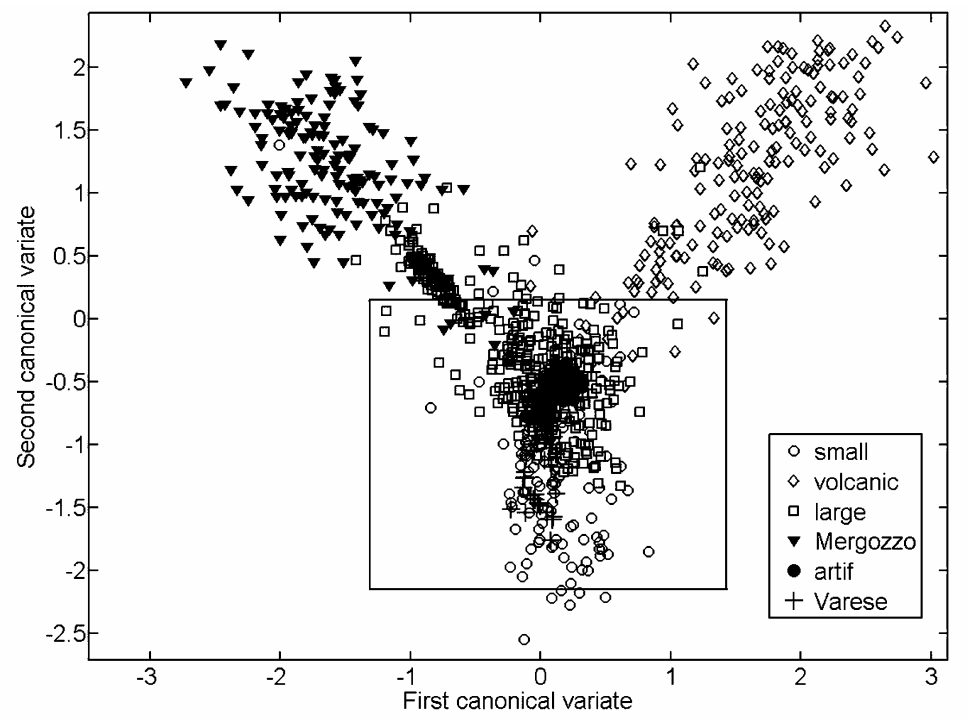

Fig. 2. Factor scores of sites in the plane of the first two axes in the canonical correlation analysis.

Tab. 4. Factor loadings of the first four canonical variates (environmental set).

\begin{tabular}{cccccccc}
\hline & $\mathrm{I}$ & & $\mathrm{II}$ & & $\mathrm{III}$ & & $\mathrm{IV}$ \\
\hline $\mathrm{NO}_{3}$ & -0.592 & $\mathrm{NH}_{4}$ & -0.445 & $\mathrm{NH}_{4}$ & -0.421 & $\mathrm{NO}_{3}$ & -0.373 \\
depth & -0.109 & $\mathrm{TP}$ & -0.390 & temp & -0.273 & $\mathrm{NH}_{4}$ & -0.369 \\
maxdepth & -0.021 & $\mathrm{vol}$ & -0.256 & alkal & -0.240 & $\mathrm{TP}$ & -0.179 \\
vol & -0.007 & alkal & -0.251 & $\mathrm{TP}$ & -0.220 & temp & -0.165 \\
$\mathrm{O}_{2}$ & 0.019 & depth & -0.246 & $\mathrm{cond}$ & -0.144 & $\mathrm{pH}$ & -0.154 \\
$\mathrm{NH}_{4}$ & 0.020 & $\mathrm{NO}_{3}$ & -0.152 & $\mathrm{sat} \mathrm{O}_{2}$ & -0.135 & cond & -0.114 \\
$\mathrm{TP}$ & 0.048 & $\mathrm{pH}$ & -0.115 & transp & -0.074 & sat $\mathrm{O}_{2}$ & -0.019 \\
sat $\mathrm{O}_{2}$ & 0.154 & maxdepth & -0.053 & $\mathrm{pH}$ & 0.060 & alkal & -0.006 \\
temp & 0.395 & cond & 0.012 & $\mathrm{O}_{2}$ & 0.136 & $\mathrm{O}_{2}$ & 0.217 \\
transp & 0.467 & temp & 0.261 & $\mathrm{NO}_{3}$ & 0.218 & maxdepth & 0.307 \\
alkal & 0.896 & $\mathrm{O}_{2}$ & 0.380 & depth & 0.311 & depth & 0.577 \\
pH & 0.915 & transp & 0.409 & vol & 0.354 & vol & 0.750 \\
cond & 0.946 & sat $\mathrm{O}_{2}$ & 0.622 & maxdepth & 0.693 & transp & 0.871 \\
\hline
\end{tabular}

Tab. 5. Factor loadings of the first canonical variate and list of abbreviations (taxa set).

\begin{tabular}{|c|c|c|c|c|c|}
\hline Spirosperma ferox Eisen, 1879 & S.fero & -0.526 & Pentaneurini spp. & Pentan & -0.048 \\
\hline Pagastiella orophila (Edward, 1929) & P.orop & -0.498 & Cladopelma spp. & Cladop & -0.004 \\
\hline Parakiefferiella bathophila (Kieffer, 1912) & P.bath & -0.475 & Psectrocladius spp. & Psectr & 0.011 \\
\hline Demicryptochironomus vulneratus (Zetterstedt, 1838) & D.vuln & -0.455 & Polypedilum spp. & Polype & 0.032 \\
\hline Stempellina spp. & Stempe & -0.420 & Chaoborus flavicans (Meigen 1830) & C.flav & 0.041 \\
\hline Stylodrilus lemani (Grube, 1879) & S.lema & -0.417 & Procladius choreus (Meigen, 1804) & P.chor & 0.054 \\
\hline Bothrioneurum vejdoskianum Stolc, 1886 & B.vejd & -0.380 & Tubifex tubifex (Müller, 1774) & T.tubi & 0.070 \\
\hline Aulodrilus spp. & Aulod & -0.343 & Dero digitata (Müller, 1774) & D.digi & 0.074 \\
\hline Prodiamesa olivacea (Meigen, 1818) & P.oliv & -0.331 & Branchiura sowerbyi Beddard, 1892 & B.sowe & 0.081 \\
\hline Uncinais uncinata (Orsted, 1842) & U.unci & -0.316 & Pisidium spp. & Pisidi & 0.091 \\
\hline Pseudochironomus prasinatus (Staeger, 1839) & P.pra & -0.292 & Nais elinguis Müller, 1774 & N.elin & 0.106 \\
\hline Micropsectra spp. & Tanyta & -0.289 & Limnodrilus spp. & Limnod & 0.144 \\
\hline Dicrotendipes spp. & Dicrot & -0.287 & Endochironomus spp. & Endoch & 0.157 \\
\hline Orthocladius spp. & Orthoc & -0.285 & Stylaria lacustris (Linnaeus, 1767) & S.lacu & 0.160 \\
\hline Micronecta $\mathrm{sp}$. & Micron & -0.282 & Microtendipes spp. & Microt & 0.219 \\
\hline Caenis sp. & Caenis & -0.274 & Potamothrix spp. & Potamo & 0.221 \\
\hline Rhyacodrilus sp. & Rhyaco & -0.254 & Paratanytarsus spp. & Parata & 0.281 \\
\hline Paralauterborniella nigrohalteralis (Malloch, 1915) & P.nigro & -0.250 & Physa spp. & Physa & 0.325 \\
\hline Psammoryctides barbatus (Grube, 1861) & P.barb & -0.231 & Stictochironomus pictulus (Meigen, 1830) & S.pict & 0.332 \\
\hline Asellus aquaticus (Linnaeus, 1758) & A.aqua & -0.204 & Chironomus plumosus (Linnaeus, 1758) & C.plum & 0.346 \\
\hline Ceratopogonidae sp. & Cerato & -0.202 & Lymnaea sp. & Lymnea & 0.378 \\
\hline Paracladopelma spp. & Paracl & -0.197 & Sphaerium ovale (Férussac, 1807) & S.ova & 0.387 \\
\hline Slavina appendiculata (Udekem, 1855) & S.appe & -0.193 & Theodoxus fluviatilis (Linnaeus, 1758) & T.fluv & 0.432 \\
\hline Bichaeta sanguinea Bretscher, 1900 & B.sang & -0.157 & Valvata piscinalis (Müller, 1774) & V.pisc & 0.438 \\
\hline Niphargus foreli Humbert, 1877 & N.fore & -0.133 & Echinogammarus spp. & Echino & 0.499 \\
\hline Chironomus anthracinus Zetterstedt, 1860 & C.anth & -0.117 & Dugesia sp. & Dugesi & 0.514 \\
\hline Lumbriculidae spp. & Lumbri & -0.090 & Paratendipes albimanus (Meigen, 1818) & P.albi & 0.576 \\
\hline Cryptochironomus spp. & Crypto & -0.082 & Bithynia tentaculata (Linnaeus, 1758) & B.tent & 0.659 \\
\hline Cladotanytarsus atridorsum Kieffer, 1924 & C.atri & -0.065 & & & \\
\hline
\end{tabular}


Tab. 6. Factor loadings of the second canonical variate (taxa set).

\begin{tabular}{|c|c|c|c|}
\hline Chaoborus flavicans (Meigen 1830) & -0.519 & Uncinais uncinata (Orsted, 1842) & 0.302 \\
\hline Chironomus plumosus (Linnaeus, 1758) & -0.171 & Sphaerium ovale (Férussac, 1807) & 0.304 \\
\hline Tubifex tubifex (Müller, 1774) & -0.153 & Lymnaea sp. & 0.308 \\
\hline Lumbriculidae spp. & -0.141 & Rhyacodrilus sp. & 0.309 \\
\hline Ceratopogonidae sp. & -0.009 & Demicryptochironomus vulneratus (Zetterstedt, 1838) & 0.311 \\
\hline Bichaeta sanguinea Bretscher, 1900 & 0.004 & Echinogammarus spp. & 0.321 \\
\hline Niphargus foreli Humbert, 1877 & 0.044 & Stempellina spp. & 0.350 \\
\hline Asellus aquaticus (Linnaeus, 1758) & 0.059 & Theodoxus fluviatilis (Linnaeus, 1758) & 0.359 \\
\hline Slavina appendiculata (Udekem, 1855) & 0.094 & Orthocladius spp. & 0.361 \\
\hline Paracladopelma spp. & 0.114 & Pisidium spp. & 0.363 \\
\hline Stylodrilus lemani (Grube, 1879) & 0.154 & Parakiefferiella bathophila (Kieffer, 1912) & 0.371 \\
\hline Stylaria lacustris (Linnaeus, 1767) & 0.162 & Valvata piscinalis Müller, 1774 & 0.376 \\
\hline Endochironomus spp. & 0.188 & Dugesia sp. & 0.386 \\
\hline Paralauterborniella nigrohalteralis (Malloch, 1915) & 0.190 & Limnodrilus spp. & 0.386 \\
\hline Physa spp. & 0.196 & Pagastiella orophila (Edward, 1929) & 0.387 \\
\hline Caenis sp. & 0.216 & Chironomus anthracinus Zetterstedt, 1860 & 0.394 \\
\hline Micronecta sp. & 0.224 & Cladopelma spp. & 0.401 \\
\hline Nais elinguis Müller, 1774 & 0.225 & Branchiura sowerbyi Beddard, 1892 & 0.412 \\
\hline Prodiamesa olivacea (Meigen, 1818) & 0.228 & Micropsectra spp. & 0.432 \\
\hline Dero digitata (Müller, 1774) & 0.228 & Dicrotendipes spp. & 0.437 \\
\hline Stictochironomus pictulus (Meigen, 1830) & 0.248 & Paratendipes albimanus (Meigen, 1818) & 0.450 \\
\hline Aulodrilus spp. & 0.256 & Cladotanytarsus atridorsum Kieffer, 1924 & 0.470 \\
\hline Potamothrix spp. & 0.258 & Pseudochironomus prasinatus (Staeger, 1839) & 0.486 \\
\hline Bothrioneurum vejdoskianum Stolc, 1886 & 0.264 & Bithynia tentaculata (Linnaeus, 1758) & 0.528 \\
\hline Psammoryctides barbatus (Grube, 1861) & 0.268 & Polypedilum spp. & 0.562 \\
\hline Paratanytarsus spp. & 0.273 & Cryptochironomus spp. & 0.565 \\
\hline Microtendipes spp. & 0.274 & Pentaneurini spp. & 0.569 \\
\hline \multirow[t]{2}{*}{ Spirosperma ferox Eisen, 1879} & 0.298 & Psectrocladius spp. & 0.580 \\
\hline & & Procladius choreus (Meigen, 1804) & 0.601 \\
\hline
\end{tabular}

Tab. 7. BQIW of 57 taxa calculated on the basis of 1060 samples.

\begin{tabular}{|c|c|c|c|}
\hline Chaoborus flavicans (Meigen, 1830) & 1.000 & Stempellina spp. & 3.824 \\
\hline Chironomus plumosus (Linnaeus, 1758) & 2.458 & Parakiefferiella bathophila (Kieffer, 1912) & 3.845 \\
\hline Asellus aquaticus (Linnaeus, 1758) & 2.687 & Pagastiella orophila (Edward, 1929) & 3.851 \\
\hline Niphargus foreli Humbert, 1877 & 2.837 & Caenis sp. & 3.854 \\
\hline Slavina appendiculata (Udekem, 1855) & 2.871 & Micronecta sp. & 3.873 \\
\hline Stylodrilus lemani (Grube, 1879) & 3.102 & Dicrotendipes spp. & 3.905 \\
\hline Tubifex tubifex (Müller, 1774) & 3.144 & Cladopelma spp. & 3.911 \\
\hline Ceratopogonidae spp. & 3.183 & Orthocladius spp. & 3.923 \\
\hline Spirosperma ferox Eisen, 1879 & 3.196 & Cryptochironomus spp. & 3.927 \\
\hline Chironomus anthracinus Zetterstedt, 1860 & 3.352 & Polypedilum spp. & 3.983 \\
\hline Lumbriculidae spp. & 3.359 & Nais elinguis Müller, 1774 & 3.986 \\
\hline Psammoryctides barbatus (Grube, 1861) & 3.369 & Pseudochironomus prasinatus (Staeger, 1839) & 3.994 \\
\hline Bichaeta sanguinea Bretscher, 1900 & 3.411 & Endochironomus spp. & 3.999 \\
\hline Prodiamesa olivacea (Meigen, 1818) & 3.420 & Branchiura sowerbyi Beddard, 1892 & 4.028 \\
\hline Paracladopelma spp. & 3.455 & Pentaneurini spp. & 4.109 \\
\hline Potamothrix spp. & 3.498 & Psectrocladius spp. & 4.140 \\
\hline Aulodrilus spp. & 3.500 & Paratanytarsus spp. & 4.154 \\
\hline Demicryptochironomus vulneratus (Zetterstedt, 1838) & 3.586 & Cladotanytarsus atridorsum Kieffer, 1924 & 4.198 \\
\hline Uncinais uncinata (Orsted, 1842) & 3.601 & Physa spp. & 4.272 \\
\hline Bothrioneurum vejdovskianum Stolc, 1886 & 3.608 & Lymnaea sp. & 4.393 \\
\hline Dero digitata (Müller, 1774) & 3.622 & Dugesia sp. & 4.425 \\
\hline Pisidium spp. & 3.661 & Valvata piscinalis (Müller, 1774) & 4.434 \\
\hline Rhyacodrilus sp. & 3.723 & Paratendipes albimanus (Meigen, 1818) & 4.462 \\
\hline Paralauterborniella nigrohalteralis (Malloch, 1915) & 3.724 & Echinogammarus spp. & 4.547 \\
\hline Limnodrilus spp. & 3.724 & Stictochironomus pictulus (Meigen, 1830) & 4.549 \\
\hline Microtendipes spp. & 3.747 & Bithynia tentaculata (Linnaeus, 1758) & 4.589 \\
\hline Procladius choreus (Meigen, 1804) & 3.776 & Theodoxus fluviatilis (Linnaeus, 1758) & 4.591 \\
\hline Stylaria lacustris (Linnaeus, 1767) & 3.795 & Sphaerium ovale (Férussac, 1807) & 4.809 \\
\hline Micropsectra spp. & 3.802 & & \\
\hline
\end{tabular}




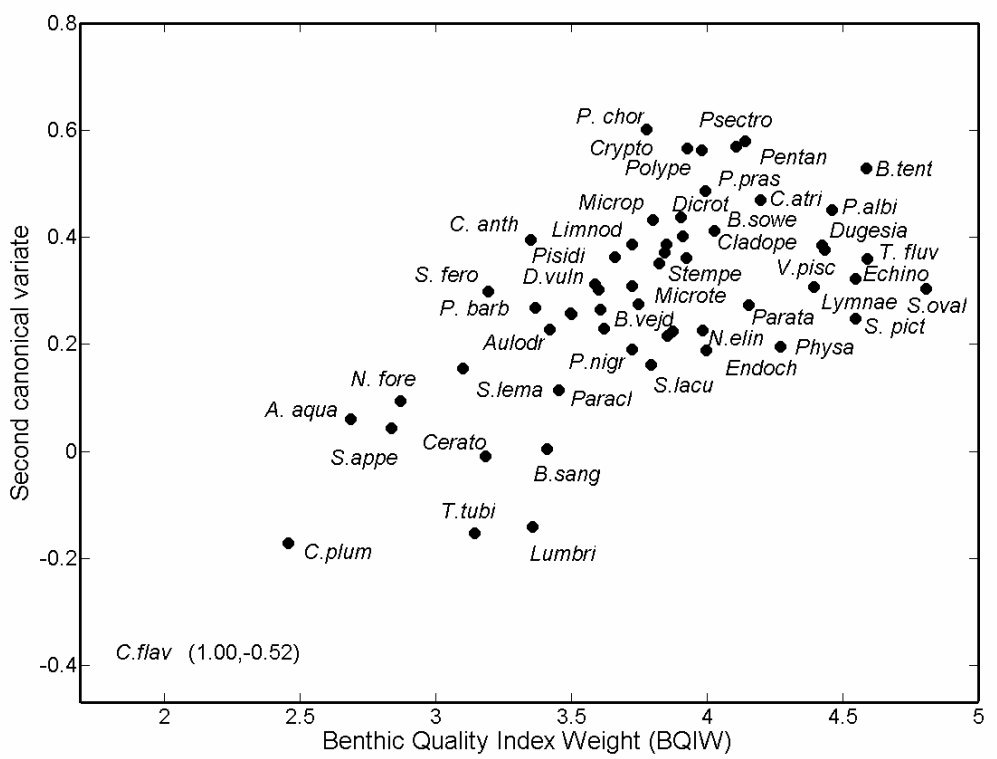

Fig. 3. Plot of BQIW against the factor loadings of the second canonical variate.

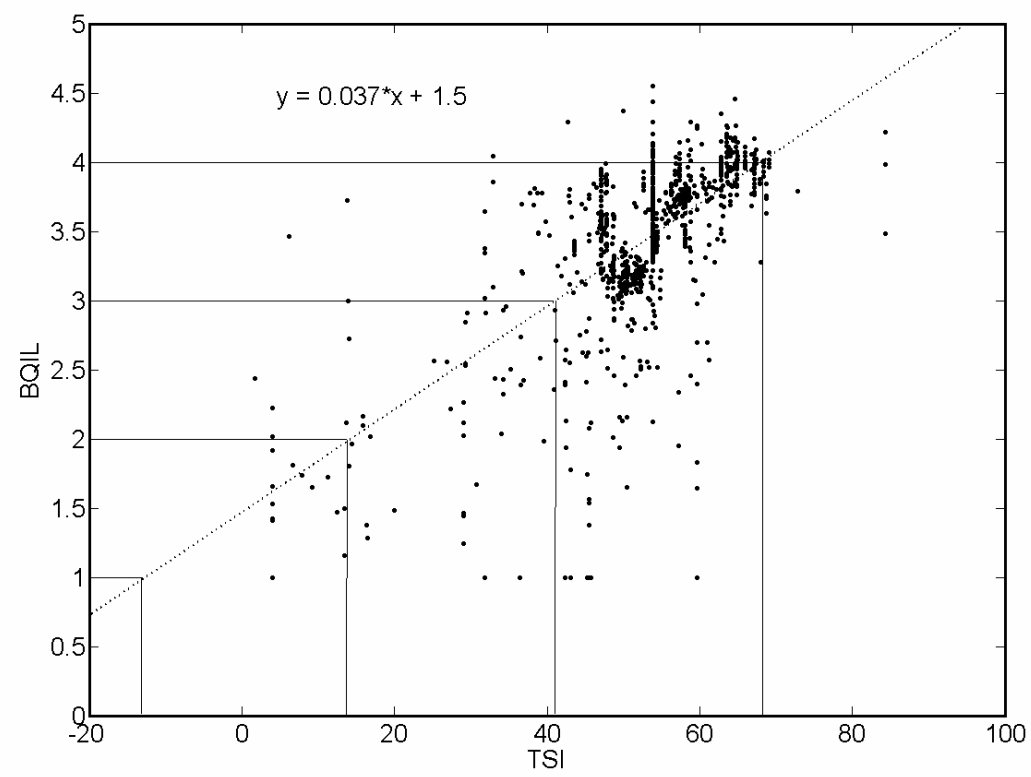

Fig. 4. Plot of the TSI value against the BQIL value calculated for each site. Minimum square line and linear correlation equation are reported.

BQIL was significantly correlated $(p<0.001)$ with the second canonical axis $(r=0.598$ and $1058 \mathrm{df})$ : the relation between $\mathrm{BQIW}$ and the factor loadings of the second canonical variate are in figure 3.

BQIL was also significantly correlated $(p<0.001)$ with the modified TSI (Fig. 4). The correlation coefficient was 0.656 with $1058 \mathrm{df}$. BQIL values could be tentatively assigned to 5 quality classes (see this paper, paragraph 3.1.). If we plot the number of sites in each class $v s$ lakes (Fig. 5), most sites should be assigned to classes 2, 3, some in class 4 , and very few are in classes 1 and 5. Most stations of the large lakes Maggiore and Garda were assigned to classes 2-3, as were the Mergozzo lake stations. Most stations of the volcanic lakes were in class 2; Varese, Annone and other small lakes had many stations in class 4 . 


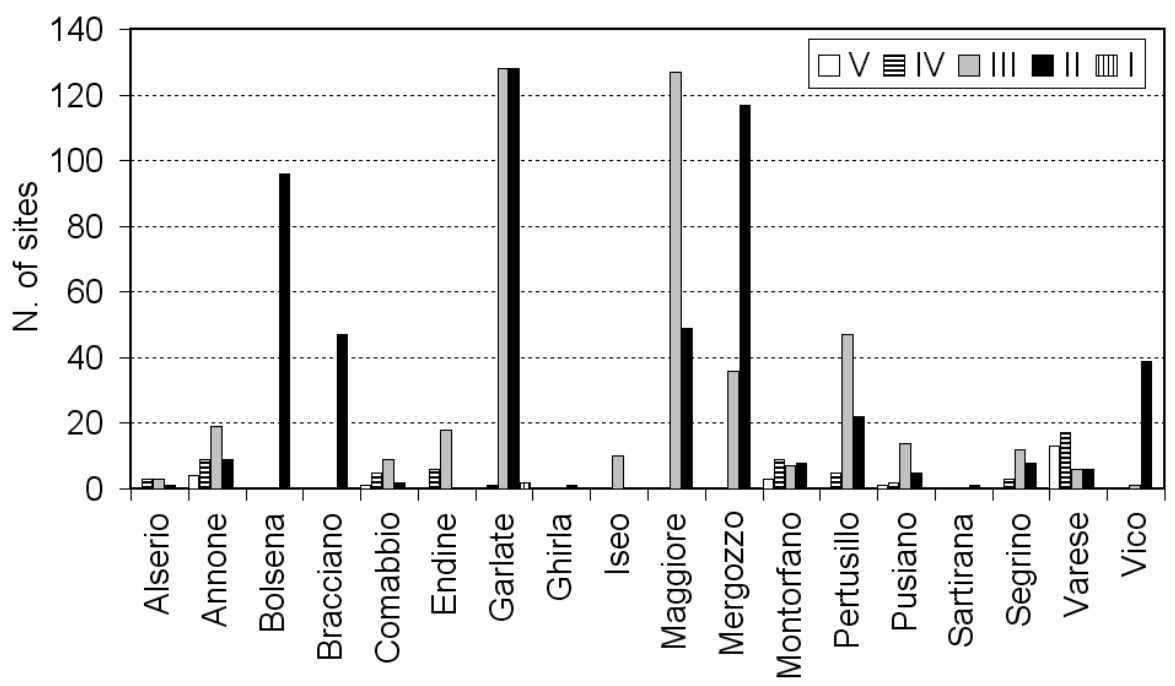

Fig. 5. Frequency of quality classes into which stations of different lakes were assigned according to BQIL values.

\section{DISCUSSION}

The benthic macroinvertebrates from Italian lakes were sampled since the '50s (Corbella et al. 1956; Nocentini 1979), but in Northern Italy few sampling campaigns were undertaken after the ' 80 s (Nocentini 1988, 1989, 1991; Bonacina et al. 1992).

The sampling effort varied considerably both in space and in time and often macroinvertebrate collection was not synchronous with water sampling. Rarely, samples were available for the same lake in different years (lakes Maggiore, Mergozzo and Varese); in these cases changes in community composition were detected (Nocentini 1979; Ruggiu \& Saraceni 1972).

CANON was carried out as a preliminary multivariate analysis to emphasize the relationships between environmental variables and macrobenthos composition. The most significant results were that different lake types, with different morphology and water chemical composition, were responsible for the different distribution of macroinvertebrate taxa. Conductivity, alkalinity and $\mathrm{pH}$ were the environmental variables accounting for the largest source of variation in the first canonical variate. Transparency, nutrients and dissolved oxygen had the highest factor loadings in the second, and lake volume and depth contributed most to the third canonical variate.

A highly significant correlation coefficient between the BQIW and the second canonical variate was observed in the lakes investigated. The correlation between oxygen, phosphorus and transparency with the second variate justified the formulation of a single indicator weight (BQIW) that summarized the response of each taxon to lake trophic status (measured as TP and transparency) and oxygenation level without separating different lake types. This was only a very rough ap- proximation because the interactions between lake's morphometry (volume, depth), natural chemical characteristics and anthropogenic factors are associated with a high number of potential macroinvertebrate colonizers, resulting in a quite variable and complex response. Seminara et al. (1990) and Borderelle et al. (2005) emphasized that the comparison between the littoral and the profundal communities were critical for developing a Biotic Index. Verneaux et al. (2004) stressed that a high content of allogenic matter in sediments can be present without high chlorophyll content in waters. The consequence is that very different lake types should require more sophisticated indexes that take into account different trophic or biogenic potential of the lake and the lake's ability to transfer available matter to consumers.

In the present paper BQIW characterized taxa, whereas BQIL characterized sites. The BQIL was used to assign different sites to different quality classes, as requested by the WFD. It must be emphasized that the assignment of BQIL into 5 quality classes must be considered very tentative, because of the heterogeneous database used. New and well planned sampling campaigns are required for the collection of new data from a larger spectrum of lake types to have a more extended range of variation to validate the indexes. In particular, the analysis of the response of deep communities in large profundal lakes (Maggiore, Como, Garda and Iseo) is needed, as is the response of Alpine lakes and brackish water ones.

The protocol developed for Italian lakes can obviously be extended to other countries. Attention should be paid to the choice of environmental variables that are aggregated to calculate BQIW. These variables should reflect the ability of species to transfer energy to different trophic levels in lakes of different natural and anthropogenic conditions. 


\section{ACKNOWLEDGEMENTS}

This work was supported by: (I) European Commission Directorate General JRC Joint Research Centre Institute for Environment and Sustainability Inland and Marine Waters Unit contract No ImwEewai-20041119-1 "Support for a Research Project on the Assessment of the Ecological State of Lakes by Macroinvertebrates In Lombardy"; (II) Italian Murst First 2003-2005: "Taxonomy, Ecology, Biogeography of Diptera Chironomidae". A sincere acknowledgement is for A.M. Nocentini and C. Bonacina (CNR Institute for Ecosystem Study - Verbania Pallanza), and for G. Bonomi (University of Bologna), who contributed to the knowledge of benthos in Italian lakes.

\section{REFERENCES}

Aagaard, K. 1986. The chironomid fauna of north Norwegian lakes, with a discussion on methods of community classification. Holarct. Ecol., 9: 1-12.

Bazzanti, M, M. Seminara \& S. Baldoni. 1998. Assessing hypolimnetic stress in a monomictic, eutrophic lake using profundal sediment and macrobenthic characteristics. $J$. Freshwat. Ecol., 13: 405-412.

Bonacina, C., G. Bonomi \& A. Pasteris. 1992. Some remarks on the macrobenthos community of the profundal zone of the large Italian lakes. Mem. Ist. ital. Idrobiol., 50: 79-106.

Bonomi, G. 1962. La dinamica produttiva delle principali popolazioni macrobentoniche del Lago di Varese. Mem. Ist. ital. Idrobiol., 15: 207-254.

Bonomi, G. 1964. Un nuovo aspetto dell'evoluzione del Lago di Varese: la comparsa di situazioni meromittiche. Mem. Ist. ital. Idrobiol., 17: 231-246.

Bonomi, G. 1974. Benton profondo. In: M. Gerletti (Ed.), Indagini sul lago di Garda. Quaderni I.R.S.A., 18: 211-223.

Bonomi, G. \& L. Adreani. 1978. Significato adattativo della struttura comunitaria e della dinamica di popolazione nel macrobenton profondo di un lago artificiale. In: Istituto Italiano di Idrobiologia (Ed.), Il lago di Pietra del Pertusillo: definizione delle sue caratteristiche limnoecologiche. Istituto Italiano di Idrobiologia: 133-201.

Bonomi, G. \& M. Gerletti. 1967. Il Lago d'Iseo: primo quadro limnologico generale (termica, chimica, plancton e benton profondo). Mem. Ist. ital. Idrobiol., 22: 149-175.

Bonomi, G. \& D. Ruggiu. 1968. Lago di Bolsena: composizione, distribuzione e biomassa del benthon profondo. Mem. Ist. ital. Idrobiol., 23: 209-244.

Bonomi, G., A. Calderoni \& R. Mosello. 1979. Some remarks on the recent evolution of the deep Italian subalpine lakes. Symp. Biol. Hung., 19: 87-111.

Bonomi, G., C. Bonacina \& I. Ferrari. 1967. Caratteristiche chimiche, plancton e benthos nel quadro evolutivo recente dei laghi briantei. Mem. Ist. ital. Idrobiol., 21: 241- 287.

Borderelle, A.L., V. Verneaux \& D. Gerdeaux. 2005. Biological quality assessment of three French Alpine lakes (Lake Annecy, Lake Crop, Lake Grand Domenon) using the Lake Biotic Index (LBI). Arch. Hydrobiol., 162: 497-509.

Brundin, L. 1949. Chironomiden und andere Bodentiere der südschwedischen Urgebirgseen. Ein Beitrag zur Kenntnis der bodenfaunistischen Charakterzüge schwedischer oligotropher Seen. Report of the Institute of Freshwater Research Drottningholm, 30: 1-915.

Brundin, L. 1956. Zur Systematik der Orthocladiinae (Diptera Chironomidae). Report of the Institute of Freshwater Research Drottningholm, 37: 5-185.

Brundin, L. 1974. Fifty years' limnic zoogeography. Mitt. int. Ver. Limnol., 20: 287-300.
Carlson, R.E. 1977. A trophic state index for lakes. Limnol. Oceanogr., 22: 361-369.

Ceretti, G. \& A.M. Nocentini. 1996. Notes on the distribution of some macrobenthonic population (Oligochaeta \& Diptera Chironomidae) in the littoral of a few small lakes in northern Italy. Mem. Ist. ital. Idrobiol., 54: 109-124.

Chiaudani, G., G.F. Gaggino \& M. Vighi. 1983. Caratteristiche chimiche e possibilità d'uso delle acque lacustri italiane. Ingegneria ambientale, 12: 212-234.

Corbella, C., N. Della Croce \& O. Ravera. 1956. Plancton, benthos e chimismo delle acque e dei sedimenti in un lago profondo (Lago Maggiore). Mem. Ist. ital. Idrobiol., 9: $125-262$.

Gaggino, G.F. \& E. Cappelletti. 1984. Catasto dei laghi italiani. CNR-IRSA, Notiziario dei Metodi Analitici, 72: $974 \mathrm{pp}$.

Gaggino, G.F., R. Marchetti, E. Cappelletti \& T. Calcagnini. 1985. La qualità delle acque dei laghi italiani negli anni '80. Proc. Lake pollution and Recovery. Roma, 1518/4/1985. EWPCF-ANIS, Roma: 33 pp.

Gittins, R. 1979. Ecological applications of canonical analysis. In: L. Orloci, C.R. Rao \& W.M. Stiteler (Eds), Multivariate methods in ecological works. Statistical Ecology, 7: 309-535.

Johnson, R., T. Wiederholm \& D.M. Rosenberg. 1993. Freshwater biomonitoring using individual organisms, populations, and taxa assemblages of benthic macroinvertebrates. In: D.M. Rosenberg \& V.H. Resh (Eds), Freshwater biomonitoring and benthic macroinvertebrates. Chapman \& Hall, New York: 40-158.

Kansanen, P.H., L. Passivirta \& T. Väyrynen. 1990. Ordination analysis and bioindices based on zoobenthos communities used to assess pollution of a lake in Southern Finland. Hydrobiologia, 220: 153-170.

Lang, C. 1985. Eutrophication of Lake Geneva indicated by the oligochaetes communities of the profundal. Hydrobiologia, 126: 237-243.

Le Foche M., T. Notargiacomo \& L. Mancini. 2005. Rassegna degli indici basati sui macroinvertebrati bentonici come indicatori di qualità degli ecosistemi lacustri. Ann. Ist. Super. Sanità, 41: 403-413.

Lek, S. \& J.F. Guégan (Eds). 2000. Artificial neuronal networks. Application to Ecology and Evolution. Springer Verlag, Berlin: 262 pp.

Lenz, F. 1925. Chironomiden und Seetypenlehre. Die Naturwissenschaften, 13: 5-10.

Lenz, F. 1954. Die Bodenfauna des Lago Maggiore und ihre Lebensbedingungen. Mem. Ist. ital. Idrobiol., 8: 273-322.

Lundbeck, J. 1936. Untersuchungen über die Bodenbesiedlung der Alpenrandseen. Arch. Hydrobiol., 10: 207-358.

Mietto, S., B. Rossaro \& V. Lencioni. 2000. The Chironomid taxa of the Italian Lakes: a review. In: O. Hoffrichter (Ed.), Proc. of the Late 20th Century Research on Chironomidae: an anthology from the 13th International Symposium on Chironomidae. Shaker Verlag, Aachen: 549-564.

Naumann, E. 1932. Grundzüge der regionalen Limnologie. Die Binnengewasser, 11. Schweizerbart'sche Verlagsbuchhandlung, Stuttgart: $176 \mathrm{pp}$.

Nocentini, A.M. 1963. Struttura e dinamica della fauna macrobentonica litorale e sublitorale del Lago Maggiore. Mem. Ist. ital. Idrobiol., 16: 189-274.

Nocentini, A.M. 1966. Struttura e dinamica della fauna macrobentonica litorale e sublitorale del Lago di Mergozzo. Mem. Ist. ital. Idrobiol., 20: 209-259.

Nocentini, A.M. 1973. La fauna macrobentonica litorale e sublitorale dei laghi Bolsena, Bracciano e Vico (Italia Centrale Lazio). Mem. Ist. ital. Idrobiol., 30: 97-148.

Nocentini, A.M. 1974. Popolamento bentonico litorale e sublitorale. In: M. Barboni (Ed.), Indagini limnologiche 
sui laghi di Bolsena, Bracciano, Vico e Trasimeno. Quaderni I.R.S.A., 17: 121-156.

Nocentini, A.M., D. Ruggiu \& C. Saraceni. 1974. Popolamento bentonico. In: Istituto Italiano di Idrobiologia (Ed.), Indagini ecologiche sul Lago d'Endine. Istituto Italiano di Idrobiologia: 260-288.

Nocentini, A.M. 1979. Variazioni temporali e spaziali della fauna macrobentonica litorale del Lago di Mergozzo. Mem. Ist. ital. Idrobiol., 37: 277-327.

Nocentini, A.M. 1988. Ecologia dei popolamenti macrobentonici lito-sublitorali del Lago Maggiore, in relazione agli apporti di origine organica. In: C.N.R. Istituto Italiano di Idrobiologia (Ed.), Ricerche sull'evoluzione del Lago Maggiore. Aspetti limnologici. Programma quinquennale 1983-1987 (Campagna 1986). Ed. Commissione Internazionale per la protezione delle acque italo-svizzere: 143149.

Nocentini, A.M. 1989. Researches on the zoobenthos. Mem. Ist. ital. Idrobiol., 46: 173 -196.

Nocentini, A.M. 1991. Indagini sull'ambiente litorale. Macrobenton litorale. In: C.N.R. Istituto Italiano di Idrobiologia (Ed.), Ricerche sull'evoluzione del Lago Maggiore. Aspetti limnologici. Programma quinquennale 1988-1992 (Campagna 1990). Ed. Commissione Internazionale per la protezione delle acque italo-svizzere: $45-61$

Rossaro, B., V. Lencioni \& C. Casalegno. 2001. Relazioni tra specie di Ditteri Chironomidi e fattori ambientali esaminate con un data base relazionale. Atti Congresso Gadio, 5-7 maggio 2001. Studi Trent. Sci. Nat., Acta Biol., 78: 201-206.

Received: January 2006

Accepted: March 2006
Ruggiu, D. \& C. Saraceni. 1972. A statistical study of the distribution and abundance of the bottom fauna of a lake undergoing accelerated eutrophication. Mem. Ist. ital. Idrobiol., 29: 169-188.

Sæther, O.A. 1979. Chironomid communities as water quality indicators. Holarct Ecol., 2: 65-74.

Sæther, O.A. 1980. The influence of eutrophication on deep lake benthic invertebrate communities. Prog. Wat. Tech. $A W P R$, Pergamon Press, 12: 161-180.

Seminara, M., M. Bazzanti \& C. Tamorri. 1990. Sublittoral and profundal chironomid (Diptera) communities of Lake Vico (Central Italy): relationship to the trophic level. Annls. Limnol., 26: 183-193.

Ter Braak, C.J.F. \& I.C. Prentice. 1988. A Theory of gradient analysis. Adv. ecol. Res., 18: 271-317.

Thienemann, A. 1954. Chironomus Leben Verbreitung und wirtschaftliche Bedeutung der Chironomiden. Die Binnengewässer, 20. Schweizerbart'sche Verlagsbuchhandlung, Stuttgart: $834 \mathrm{pp}$.

Verneaux, V., J. Verneaux, A. Schmitt,, C. Lovy \& J.C. Lambert. 2004. The Lake Biotic Index (LBI): an applied method for assessing the biological quality of lakes using macrobenthos; the Lake Châlain (French Jura) as an example. Annls. Limnol., 40: 1-9.

Wiederholm, T. 1980. Use of benthos in lake monitoring. $J$. Wat. Pollut. Cont. Fed., 52: 537-547.

Wiederholm, T. 1981. Associations of lake-living Chironomidae. A cluster analysis of Brundin's and recent data from Swedish lakes. Rev. suisse Hydrol., 43: 140-141. 